\title{
LETTER TO THE EDITOR
}

\section{ANALOGIES IN MEDICINE: GIMLET IN CHAGAS DISEASE}

Belo Horizonte, October 2012

\section{Dear Sir}

A gimlet (Port. verruma. Esp. barrena) is a hand tool for drilling small holes, mainly in wood, without splitting. A gimlet is always a small tool for boring holes, consisting of a shaft with a pointed screw at one end and a handle at right angles at the other. A similar tool of larger size is called an auger. The cutting action of the gimlet is slightly different from an auger, however, as the end of the screw, and so the initial hole it makes, is smaller; the cutting edges pare away the wood which is moved out by the spiral sides, falling out through the entry hole. This also pulls the gimlet further into the hole as it is turned; unlike a bradawl, pressure is not required once the tip has been drawn in. The name "gimlet" comes from the Old French. The term is also used figuratively to describe something as sharp or piercing, and also to describe the twisting, boring motion of using a gimlet.

David Gruby (1810-1898), a Hungarian microbiologist and physician, is considered the founder of medical microbiology. He was the son of a poor Jewish peasant in a village at Baczka, a fertile district of southern Hungary. He received his first instruction in secular knowledge from a medical student who worked as a substitute teacher in Kis-Kér and lodged in Gruby's father's home. In 1824 or 1825 he left Kis-Kér to seek further education in Pest ${ }^{1}$.

His early years had been marked by great poverty, hardship, and prejudice. However, his great talent and determined pursuit of his aim enabled him to succeed in completing his secondary studies at the Piarist Gymnasium in Pest. In 1828 Gruby, then in the fifth year of his studies, went to Vienna to study medicine. He was a hard-working student and particularly concerned himself with anatomy under Christian Joseph Berres (1796-1844), professor of gross macroscopic anatomy. He graduated on August 5, 1839.

Some of Gruby's early microscopic observations on pathological morphology were included in his dissertation, which contains microscopic observations (with 103 illustrations) on the pathology of body fluids mucus, sputum, pus, pseudomembranes, coagula, and saliva - and compares pathological with normal findings. His attempt at microscopic differentiation of pus from other pathological substances was a careful, original investigation in a new field of medicine. Gruby demonstrated, among other things, that every one of the studied body fluids contained living elements (leukocytes). He republished his dissertation as the first part of a larger treatise on microscopic pathology, but the other planned parts never appeared ${ }^{1}$.

He received his doctorate in Vienna and performed scientific research in Paris. Grubby is remembered as a pioneer in the fields of microbiology and medical mycology. In 1843 Gruby discovered an animal parasite in the blood of the frog that he called trypanosome because the motion of the mobile organism reminded him of the action of a corkscrew. His words were: "Je propose de nommer cet hématozoaire trypanosome" (using the greek elements: Trypanon, a gimlet or auger, plus soma, body). Recherches et observations sur une nouvelle espèce d'hématozoaire, Trypanosome sanguinis. Comptes rendus hebdomadaire des séances de l'Académie des Sciences, Paris, 1843, 17: 1134-1136, p. $1135^{1,4}$. Therefore the term trypanosoma criated by Gruby was applied to a genus of protozoa comprising many hemoflagellates parasitic in invertebrates and vertebrates, including humans; several species are pathogenic (Fig. 1).

Chagas disease - American trypanosomiasis - is caused by a flagellated protozoan named Trypanosoma cruzi (Chagas, 1909). It is widely distributed in American continents southern part of the United States to southern of Argentina. In acute Chagas disease, which is mild in most individuals, cardiac damage results from invasion of myocardial cells by the organism and from consequent myocarditis. In chronic Chagas disease damage to myocardial cells and to conductive pathways causes a dilated myocardiopathy and cardiac arrythmias, whereas damage to the myenteric plexus causes megacolon and megaesophagus ${ }^{2,3}$. African trypanosomiasis - sleeping sickness - is caused by Trypanosoma gambiense or T. rhodesiense. The early stage is manifested by hemolymphatic involvement with intermittent fever, anemia and edema. Later, invasion of the central nervous system, with resultant meningoencephalitis, leading to extreme mental and physical lethargy, eventually coma and death.

Gruby was also one of the most popular practicians in Paris, famous for the extravagant cures prescribed for his distinguished patients. Among them were Frédéric Chopin (a Polish composer and virtuoso pianist of French-Polish parentage), Alexandre Dumas, père (a historical novelist writing The Three Musketeers and The Count of Monte Cristo), George Sand (a French novelist and memorialist), Alphonse Lamartine (a French statesman-politician, poet and historian) and Franz Liszt (a Hungarian composer and a virtuoso pianist, regarded by most as the greatest pianist of all time). These prescriptions were actually clever applications of psychosomatic medicine ${ }^{1}$.

José de Souza ANDRADE-FILHO

Faculdade de Ciências Médicas de Minas Gerais

Belo Horizonte, Minas Gerais, Brasil

E-mail: labjsouzandrade@terra.com.br

\section{REFERENCES}

1. David Gruby. Available from: www.whonamedit.com/doctor.cfm/3066.html

2. Kumar V, Abbas AK, Fausto N. Robbins and Cotran pathologic basis of disease. $7^{\text {th }}$ ed. Philadelphia: Elsevier Saunders; 2005. p. 405-6.

3. Pena GP, Andrade-Filho JS. Analogies in medicine: valuable for learning, reasoning, remembering and naming. Adv Health Sci Educ Theory Pract. 2010;15:609-19.

4. Skinner HA. The origin of medical terms. $2^{\text {nd }}$ ed. Baltimore: Williams \& Wilkins; 1961 